\title{
Plant-Derived Carbon Sources for Anaerobic Soil Disinfestation in Southern California
}

\author{
Oleg Daugovish ${ }^{1,}$, Joji Muramoto ${ }^{2}$, Carol Shennan ${ }^{3}$ and Margherita Zavatta ${ }^{3}$ \\ ${ }^{1}$ University of California, Agriculture and Natural Resources, Ventura, CA, 93003, USA. \\ 2University of California, Agriculture and Natural Resources, Santa Cruz, CA, 95064, USA. \\ 3University of California, Environmental Studies Department, Santa Cruz, CA, 95064, USA.
}

\section{ARTICLE INFO}

Article Type: Research Article

Keywords:

Soil-borne pathogens

Carbon to nitrogen ratio

Anaerobic soil disinfestation

Organic strawberry production

Soil chemistry and microbiology

Timeline:

Received: September 12, 2021

Accepted: October 14, 2021

Published: November 15, 2021

Citation: Daugovish O, Muramoto J, Shennan C, Zavatta M. Plant-Derived Carbon Sources for Anaerobic Soil Disinfestation in Southern California. Glob J Agric Innov Res Dev. 2021; 8: 169-175.

DOI: https://doi.org/10.15377/2409-9813.2021.08.13

\begin{abstract}
Anaerobic soil disinfestation (ASD) has been optimized and adopted as an organic alternative to chemical fumigation by strawberry growers in California. The ASD process relies on mixing labile carbon sources into the soil to generate chemical, physical, and microbiological changes aiding suppression of the soil-borne pathogens and enhancing fruit production. Continued ASD adoption is hindered by the increasing cost of rice bran, currently the most widely used carbon source. To address this need and to find suitable and economical alternative carbon sources, we conducted field evaluations of locally produced or sourced plant-based products. ASD with incorporated grass-sod clippings spent grain and coffee grounds from one supplier provided a $47 \%$ to $83 \%$ increase in fruit yields compared to untreated soil, but coffee grounds from a different supplier decreased strawberry yields. Carbon, nitrogen, and their ratios had important impacts on the efficacy of ASD with coffee grounds and grape pomace. ASD with wheat midds at 20 t/ha provided strawberry yields similar to chloropicrin-fumigated soil while substituting $30 \%$ of rice bran carbon rate with on-site grown cereal cover crop biomass resulted in yields similar to the full rate of rice bran but at a reduced cost. As we continue exploring cost-effective methods of soil disinfestation, we utilize ASD integrated with other pest management tools, such as the use of resistant cultivars and crop rotation for sustainable production.
\end{abstract}

*Corresponding Author

Email: odaugovish@ucanr.edu

Tel: +1 805-645-1454

(c) 2021 Daugovish et al. Published by Avanti Publishers. This is an open access article licensed under the terms of the Creative Commons Attribution Non-Commercial License which permits unrestricted, non-commercial use, distribution and reproduction in any medium, provided the work is properly cited. (http://creativecommons.org/licenses/by-nc/4.0/) 


\section{Introduction}

California produces approximately 706,000 tons of strawberry fruit annually, nearly $80 \%$ of all strawberries produced in the United States [1]. Similar to other production regions in the US, California experiences challenges with increasing costs and labor, land and pest management exacerbated by climate change-induced weather variability, and regulatory policies [2-3]. Due to increasing costs and restrictions on fumigant use, research has focused on developing non-fumigant alternatives to chemical applications to the soil. These alternative technologies place greater emphasis on an integrated approach to soil pests and plant-soil environment management compared to standard chemical fumigation [4]. Anaerobic soil disinfestation (ASD) was developed in the Netherlands [5] and Japan [6] as a biological alternative to fumigants to control soil-borne pathogens and nematodes in strawberries and vegetables. Anaerobic conditions in soil are created by incorporating readily available carbon sources, covering the soil with a plastic tarp, and irrigating to field capacity. The tarp is left in place to maintain soil moisture above field capacity and to sustain anaerobic conditions. Anaerobic decomposers respire using the added carbon, which results in a buildup of anaerobic byproducts that are toxic to pathogens. These byproducts degrade rapidly once the tarp is removed or holes are punched through the tarp for planting [7]. In California, ASD has been shown to be effective in reducing Verticillium dahliae microsclerotia in soil by $80 \%$ to $100 \%$, and to be able to provide marketable fruit yields comparable to fumigation in strawberry systems [8]. Recent trials showed that ASD was also effective in reducing Fusarium wilt incidence (caused by Fusarium oxysporum f. sp. fragariae) at soil temperatures above $30^{\circ} \mathrm{C}$ [9] and the development of charcoal rot of strawberry (caused by Macrophomina phaseolina) [10]. Continued adoption of ASD in California is challenged by the increasing cost of rice bran, currently the most commonly used carbon source in the state. Therefore, recent research has focused on finding effective carbon products that are locally produced or sourced and are more affordable to growers than rice bran [11]. The objective of these field trials was to evaluate carbon sources for their potential to generate anaerobic conditions and resulting effects on strawberry fruit production in coastal California.

\section{Materials and Methods}

Site characteristics and soil properties [12] for the five field trials that evaluated carbon sources for ASD are provided in Table 1. All experiments utilized randomized complete block design with four replications of treatments and included untreated controls (except for Ventura 2019-2020 that had three replications without untreated control). The ASD process was accomplished by incorporating carbon sources into the top $30-35 \mathrm{~cm}$ of soil, placing irrigation drip lines, covering beds with plastic (with sides buried in furrows), and irrigating 3-5 days later according to previously developed protocols [13]. After initiation of the ASD process in all trials (except for Santa Paula 2019-2020), oxidation/reduction potential (ORP mV) was automatically monitored every 30 sec in all treatments with oxidation/reduction potential sensors (S500CD-ORP, Sensorex. Garden Grove, CA, USA) installed at $15 \mathrm{~cm}$ soil depth connected to a data logger (CR1000, Campbell Scientific, Logan, UT, USA). The ORP reading in mV was converted to Eh $\mathrm{mV}$ by adding $199 \mathrm{mV}$. To compare intensity of anaerobic conditions, the cumulative Eh mV hours under $200 \mathrm{mV}$ were calculated for each pot using hourly averages of soil Eh. The value of $200 \mathrm{mV}$ was selected as the threshold below which soil was considered anaerobic at a soil pH of 6.58 [13].

In all trials after two to three weeks after ASD process initiation, 15-cm holes were punched through plastic in four rows per bed (and $35 \mathrm{~cm}$ between holes) in preparation for planting, which also provided bed aeration. Within 24 to 48 hours after cutting holes, bare-root strawberry transplants from high elevation nurseries were planted by hand during the second week of October in all trial sites and managed according to standard strawberry production practices [14]. During the first three months after planting strawberries, 4-6 soil cores were taken at 0-30 cm depth with a $2.5 \mathrm{~cm}$ diameter soil probe at each plot in all trials for available macro- and micronutrient analyses at Fruit Growers laboratory at Santa Paula, CA, USA.

\subsection{Oxnard, 2015-2016}

Rice bran and grape pomace were applied by hand to $1.2 \mathrm{~m}$ wide and $12 \mathrm{~m}$ long bed sections, while untreated plots did not receive any amendments. All plots were rototilled and reshaped in the same pass with a tractor implement. Next, two low-flow irrigation drip lines (John Deere, Moline, IL or Aqua-Traxx® Toro Ag., Rome, Italy) 
were placed at $5 \mathrm{~cm}$ depth in all beds, approximately $45 \mathrm{~cm}$ from bed edges. These drip lines were delivering about $4 \mathrm{~L} / \mathrm{min} . / 100 \mathrm{~m}$. Beds were covered with totally impermeable film (AGRO-TIF, no pigment/natural clear, 1mil-thick; USA Extruded Plastics, Anaheim, CA) and irrigated $(0.01 \mathrm{ha} / \mathrm{m})$ via drip lines within $72 \mathrm{~h}$ to help generate anaerobic conditions in the soil. After completion of the ASD process, the short-day cultivar 'Ventana' was planted in this organically certified field. Fruits were harvested from marked 20 plants in each plot from December until March, two to three times a week, separated into marketable and unmarketable categories according to established standards [14], and weights were recorded.

Table 1: Experimental sites and carbon sources evaluated for anaerobic soil disinfestation for strawberry production in coastal California, USA.

\begin{tabular}{|c|c|c|}
\hline Experimental Sites, and Trial Seasons & Soil Characteristics & Carbon Sources Tested and Application Rates \\
\hline Oxnard, 2015-2016 & $\begin{array}{l}65 \% \text { sand, } 12 \% \text { clay, } 22 \% \text { silt; } p H \\
7.8 \text { and } 1.1 \% \text { organic matter }\end{array}$ & $\begin{array}{l}\text { 1. Rice bran at } 20 \mathrm{t} / \mathrm{ha} \\
\text { 2. Grape pomace at } 20 \mathrm{t} / \mathrm{ha}\end{array}$ \\
\hline Santa Paula, 2015-2016 & $\begin{array}{l}75 \% \text { clay, } 25 \% \text { silt; } \mathrm{pH} 7.6 \text { and } \\
1.2 \% \text { organic matter }\end{array}$ & $\begin{array}{l}\text { 1. Coffee grounds from supplier } 1 \text {, all at } 20 \mathrm{t} / \mathrm{ha} \\
\text { 2. Sod (grass) clippings at } 20 \mathrm{t} / \mathrm{ha} \\
\text { 3. Spent grain (brewery waste) at } 20 \mathrm{t} / \mathrm{ha}\end{array}$ \\
\hline Oxnard, 2016-2017 & $\begin{array}{l}20 \% \text { clay, } 40 \% \text { silt, } 40 \% \text { sand; } \mathrm{pH} \\
8.1 \text { and } 2.5 \% \text { organic matter }\end{array}$ & Coffee grounds from supplier 2 at 20 t/ha \\
\hline Santa Paula, 2019-2020 & $\begin{array}{l}75 \% \text { clay, } 25 \% \text { silt; } \mathrm{pH} 7.4 \text { and } \\
1.3 \% \text { organic matter }\end{array}$ & Midds (wheat millfeed) at $20 \mathrm{t} / \mathrm{ha}$ \\
\hline Ventura, 2019-2020 & $\begin{array}{l}20 \% \text { clay, } 39 \% \text { silt, } 41 \% \text { sand; } \mathrm{pH} \\
7.2 \text { and } 1.3 \% \text { organic matter } 3 \%\end{array}$ & $\begin{array}{l}\text { 1. Rice bran at } 20 \mathrm{t} / \mathrm{ha} \text {, } \\
\text { 2. Rice bran at } 13.4 \mathrm{t} / \mathrm{ha} \text { supplemented by } 6.6 \mathrm{t} / \mathrm{ha} \\
\text { rye cover crop biomass } \\
\text { 3. Rice bran at } 13.4 \mathrm{t} / \mathrm{ha} \text { supplemented by } 6.6 \mathrm{t} / \mathrm{ha} \\
\text { barley cover crop biomass }\end{array}$ \\
\hline
\end{tabular}

\subsection{Santa Paula, 2015-2016}

Coffee grounds (supplier 1), sod grass, clippings, and spent grain (all sourced within $20 \mathrm{~km}$ from trial site) were applied to bed tops by hand and incorporated with a pitchfork into $1.2 \mathrm{~m}$ wide and $3 \mathrm{~m}$ long plots, $35 \mathrm{~cm}$ deep. Application of plastic, irrigation, and plot management were the same as described for Oxnard, 2015-2016.

Short-day strawberry 'Fronteras' transplants were planted in all plots, and fruit yields were determined as described for Oxnard, 2015-2016.

\subsection{Oxnard, 2016-2017}

Coffee grounds from supplier 2 (sourced within $15 \mathrm{~km}$ from application site) were applied by cone spreader mounted to tractor in an organic field to $6 \mathrm{~m}$ by $30 \mathrm{~m}$ plots.

After spreading, beds were constructed and shaped, incorporating coffee grounds. The proprietary cultivar 'Marquis' was planted following the completion of the ASD process. Due to poor plant performance, no fruit yield data was collected in this trial.

\subsection{Santa Paula 2019-2020}

Midds (wheat mill feed) from a supplier located $120 \mathrm{~km}$ from the trial site were applied to bed tops by hand and incorporated with a fork into $1.2 \mathrm{~m}$ wide and $2 \mathrm{~m}$ long plots, $35 \mathrm{~cm}$ deep. Application of plastic, irrigation, and plot management were the same as described for Oxnard, 2015-2016. Five weeks after initiation of the ASD process, Short-day strawberry cultivars 'Petaluma', 'Victor', and 'Warrior' were planted in all plots, and fruit yields determined Jan - May as described for Oxnard, 2015-2016. 


\subsection{Ventura 2019-2020}

Plots in this organically certified field were $12 \mathrm{~m}$ wide and $78 \mathrm{~m}$ long. Barley or rye was seeded in July in the fallow field, while plots that were assigned rice bran only were left bare. Before the termination and incorporation of cover crops, biomass was collected from four $1 \mathrm{~m}^{2}$ quadrats in all plots and dried for three days at $70{ }^{\circ} \mathrm{C}$ to estimate its dry biomass contribution to the following ASD process (Table 1). In plots without cover crops, rice bran (from a supplier $300 \mathrm{~km}$ away) was applied at a full rate of $20 \mathrm{t} / \mathrm{ha}$, while in plots with either of the two cover crops, the bran rate was reduced approximately by 30\%, accounting for the contributions by rye and barley cover crops that produced similar biomass at the time of incorporation. Short-day strawberry 'Fronteras' transplants were planted in all plots, and fruit yields were determined from 20-plant subplots as described for Oxnard, 20152016.

At each experiment and site, analyses of variance and differences between treatment means were determined using Fisher's least significant difference test $(P>0.05)$. All statistical computations were performed using SAS (version 9.3; SAS Institute, Cary, NC).

\section{Results}

\subsection{Oxnard, 2015-2016}

Rice bran incorporation produced stronger anaerobic conditions compared to grape pomace, while untreated soil remained in an aerobic state (Table 2). Availability of nitrate to strawberry plants after the completion of ASD was also greater in rice bran treatment compared to grape pomace at both sampling times: three weeks after transplanting and in the middle of fresh market production season (Table 2). Ventana strawberry plants in grape pomace plots were consistently smaller than in rice bran plots (and similar to untreated plots) and exhibited symptoms of nitrogen deficiency (data not shown). As a result of poor plant growth, fruit yields were reduced by $32 \%$ in pomace plots and $48 \%$ in untreated soil compared to rice bran plots (Table 2 ).

\subsection{Santa Paula, 2015-2016}

All carbon sources in this trial produced strong sustained anaerobic conditions during the ASD process, while untreated soil remained in an aerobic state (Table 2). Nitrate nitrogen levels at the two sampling times were highest in plots with sod clippings and generally within the sufficiency range [11] for strawberry production in all treatments (including pre-plant fertilized untreated control) (Table 2). All carbon sources evaluated for ASD in this trial provide significant (55\% to 89\%) fruit yield improvements compared to yields in untreated soil (Table 2).

\subsection{Oxnard, 2016-2017}

Coffee grounds from supplier 2 used in this trial differed in analyses from the grounds from supplier 1, which were used Santa Paula 2016-2017 trial (Table 3). Even though the carbon to nitrogen ratios were similar among the two suppliers, the contents of both carbon and nitrogen were 2.5 and 2.6 times, respectively, lower in grounds from supplier 2 compared to supplier 1 . Although the roasting process is proprietary, the analyses also showed 3.4 times greater ash content in grounds from supplier 2 compared to supplier 1, suggesting more extensive roasting and possible losses of nitrogen and carbon during the process. Even though incorporation of coffee grounds resulted in strong anaerobic conditions, the nitrate-nitrogen levels in the root zone after planting were extremely low (Table 1), and strawberry plants exhibited obvious symptoms of nitrogen deficiency and grew poorly (data not shown). Thus no yield data were collected in that trial.

\subsection{Santa Paula 2019-2020}

Even though anaerobic conditions were not measured in this trial, aromatic volatiles expected during the fermentation process were released and were easy to sense in plots where midds were incorporated. Nitrate nitrogen levels were lower than in plots with midds compared to pre-plant fertilized untreated soil (Table 1) but within the sufficiency range for strawberries [14]. Averaged over three strawberry cultivars, fruit yields in midds 
plots were $29 \%$ greater than in untreated soil (fumigated with $330 \mathrm{~kg} / \mathrm{ha}$ of chloropicrin 18-month prior to this ASD trial) (Table 1). Individually, fruit yield improvements in tested cultivars due to ASD with midds were: $62 \%$ for Petaluma, 28\% for Warrior, and 10\% for Victor.

Table 2: Anaerobic conditions, post-plant soil nitrogen and marketable strawberry fruit yields at five anaerobic disinfestation (ASD) trial sites where carbon sources were evaluated in coastal California, USA.

\begin{tabular}{|c|c|c|c|c|}
\hline $\begin{array}{l}\text { Experimental Sites, } \\
\text { and Trial Seasons }\end{array}$ & Treatments & $\begin{array}{l}\text { Cumulative Eh mV } \\
\text { below } 200 \mathrm{mv}(\mathrm{mV} \text { hrs) }\end{array}$ & $\begin{array}{l}\text { Nitrate Nitrogen } \\
(\mathrm{ppm}) \text { at } 0-30 \mathrm{~cm}\end{array}$ & $\begin{array}{l}\text { Marketable Fruit } \\
\text { Yields (g/20 Plants) }\end{array}$ \\
\hline $\begin{array}{l}\text { Oxnard, } \\
2015-2016\end{array}$ & $\begin{array}{l}\text { Rice bran } \\
\text { Grape pomace } \\
\text { Untreated }\end{array}$ & $\begin{array}{c}61,461 \text { at } 17 d \\
32,274 \text { at } 17 d \\
1,328 \text { at } 13 d\end{array}$ & $\begin{array}{c}33 \text { (Nov 4); } 18 \text { (Feb. 11) } \\
5 \text { (Nov 4); } 3 \text { (Feb. 11) } \\
14 \text { (Nov 4); } 6 \text { (Feb. 11) }\end{array}$ & $\begin{array}{l}4400 a^{a} \\
3000 b \\
2300 b\end{array}$ \\
\hline $\begin{array}{l}\text { Santa Paula, } \\
\text { 2015-2016 }\end{array}$ & $\begin{array}{l}\text { Spent grain } \\
\text { Coffee grounds (1) } \\
\text { Sod clippings } \\
\text { Untreated * }\end{array}$ & $\begin{array}{l}51,434 \text { at } 14 \mathrm{~d} \\
36,046 \text { at } 15 \mathrm{~d} \\
132,922 \text { at } 15 \mathrm{~d} \\
132 \text { at } 12 \mathrm{~d}^{\mathrm{b}}\end{array}$ & $\begin{array}{l}125 \text { (Nov 5); } 92 \text { (Feb. 12) } \\
63 \text { (Nov 5); } 33 \text { (Feb. 12) } \\
147 \text { (Nov 5); } 92 \text { (Feb. 12) } \\
66 \text { (Nov 5); } 44 \text { (Feb. 12) }\end{array}$ & $\begin{array}{l}4100 \mathrm{a} \\
5000 \mathrm{a} \\
4000 \mathrm{a} \\
2650 \mathrm{~b}\end{array}$ \\
\hline $\begin{array}{l}\text { Oxnard, } \\
2016-2017\end{array}$ & $\begin{array}{c}\text { Coffee grounds (2) } \\
\text { Untreated }\end{array}$ & $\begin{array}{c}43,890 \text { at } 20 d \\
50 \text { at } 4 d\end{array}$ & $\begin{array}{l}2 \text { (Nov 6); } 4 \text { (Feb. 12) } \\
14 \text { (Nov 6); } 7 \text { (Feb. 12) }\end{array}$ & \\
\hline $\begin{array}{l}\text { Santa Paula, } \\
\text { 2019-2020 }\end{array}$ & $\begin{array}{c}\text { Midds } \\
\text { Untreated* }\end{array}$ & & $\begin{array}{l}126 \text { (Oct.25); } 60 \text { (May. 25) } \\
245 \text { (Oct.25); } 45 \text { (May 25) }\end{array}$ & $\begin{array}{l}7500 a \\
5830 b\end{array}$ \\
\hline $\begin{array}{l}\text { Ventura, } \\
2019-2020\end{array}$ & $\begin{array}{l}\text { Rice bran } 20 \mathrm{t} / \mathrm{ha} \\
\text { Rice bran at } 13.4 \mathrm{t} / \mathrm{ha}+6.6 \mathrm{t} / \mathrm{ha} \\
\text { rye biomass } \\
\text { Rice bran at } 13.4 \mathrm{t} / \mathrm{ha}+6.6 \mathrm{t} / \mathrm{ha} \\
\text { barley biomass }\end{array}$ & $\begin{array}{l}48,892 \text { at } 13 d \\
65,057 \text { at } 13 d \\
45,807 \text { at } 13 d\end{array}$ & $\begin{array}{l}4 \text { ( May 18) } \\
6 \text { (May 18) } \\
9 \text { (May 18) }\end{array}$ & $\begin{array}{l}8150 a \\
8000 a \\
9300 a\end{array}$ \\
\hline
\end{tabular}

*Untreated beds received $550 \mathrm{~kg} / \mathrm{ha}$ of 18-6-8 pre-plant fertilizer.

aDifferent letters next to fruit yield means within each experimental site indicate significant differences among treatments according to Fisher's LSD test ( $>>0.05$ ).

${ }^{\mathrm{b}} \mathrm{A}$ single electrode (one in four replicated plots) was used to determine Eh $\mathrm{mV}$ in the untreated check at this trial site.

Table 3: Analyses of coffee grounds from two suppliers evaluated for anaerobic soil disinfestation at Santa Paula 2015-2016 (Supplier 1) and Oxnard 2016-2017 (Supplier 2).

\begin{tabular}{|c|c|c|}
\hline Analytical Parameters & Coffee Grounds from Supplier 1 & Coffee Grounds from Supplier 2 \\
\hline \hline Total $\mathbf{N}, \%$ & 2.4 & 0.9 \\
\hline Total C, \% & 54.1 & 22 \\
\hline C:N ratio & $22: 1$ & $24: 1$ \\
\hline Total $\mathbf{P}_{\mathbf{2}} \mathbf{O}_{\mathbf{5}}, \%$ & 0.1 & 0.1 \\
\hline Total $\mathbf{K}_{\mathbf{2}} \mathbf{\%}$ & 0.26 & 0.23 \\
\hline $\mathbf{E C}, \mathbf{d S} \mathbf{m}$ & 3.5 & 3.1 \\
\hline $\mathbf{P H}$ & 6.1 & 5.6 \\
\hline Ash $\%$ & 2.5 & 8.4 \\
\hline Moisture\% & 63 & 24 \\
\hline
\end{tabular}

\subsection{Ventura 2019-2020}

In this trial, about a $33 \%$ reduction in the application rate of rice bran and replacement of bran carbon with rye or barley cover crop biomass did not result in significant changes compared with ASD at full rate (20 t/ha) of rice bran alone. Anaerobic conditions, nitrogen levels, and season-long 'Fronteras' fruit yields were similar in all 
treatments (Table 1). In May, soil nitrate-nitrogen levels were low in all treatment plots as in-season fertigation likely was insufficient for the needs of this high-yielding short-day strawberry cultivar.

\section{Discussion}

These trials showed that plant-based carbon sources could have different effects on ASD efficacy and strawberry performance. Even when satisfactory anaerobic conditions were achieved, nitrogen deficiencies after applying some carbon sources negatively affected strawberry growth and fruit yields. These deficiencies are often difficult to correct cost-effectively in organic fertigation programs, which are usually less efficient in synchronizing plant demand with supply compared to conventional production systems.

With the cost of rice bran commonly used for ASD reaching $\$ 350 /$ ton, there is continued interest in finding more economical alternatives to it. In the case of coffee grounds that were available at no cost locally from supplier 2, the issue with depletion of plant-available nitrogen occurred due to great variation of the composition of these grounds from those used previously (supplier 1). In the case of using cover crops with reduced bran, the costs of growing the crops are minimal, but the time necessary to produce sufficient biomass and availability of water in drought-prone California for the non-cash crop can limit opportunities for cover cropping in current strawberry production systems. Additional considerations (besides costs) in the selection of carbon sources for ASD in production strawberry include ease of application, proximity to a reliable supplier, availability of necessary quantities on demand or/and capacity for safe storage, and acceptance by organic certification programs.

Since the synthetic chemical soil fumigates are phased out or face increasing regulatory restrictions, the need for reliable and economical alternatives increases [4]. ASD has found adoption because it has been effective in controlling key soil-borne pathogens in strawberries and maintaining fruit yields $[8,10]$ and can remain a viable industry practice if cost-effective. Diversifying suitable carbon sources, essential for successful ASD, can lead to the economic sustainability of this technology in the future. It is well recognized [4] that integrating this technology with other production and pest management tools (such as the use of resistant strawberry cultivars) will be needed to sustain fruit production in non-fumigated and organically certified fields in coastal California [4].

\section{Acknowledgments}

We would like to acknowledge USDA-NIFA Methyl Bromide Transition Program grant number 2012-5110220294 and USDA-NIFA Specialty Crop Research Initiative Program grant number 2017-51181-26832 for providing grant funding for this work and cooperators (Otillo farms, Solimar Berry Farms, and UC Hansen Research and Extension Center personnel) for help in conducting research trials.

\section{References}

[1] National Berry Report. 2019. USDA Agricultural Marketing Service; USDA Fruit and Vegetable Market News On line at: https://www.marketnews.usda.gov/mnp/fv-home.

[2] Daugovish O. Current status and distribution of pest problems in southern California and pros's and con's of disinfestation practices. Proceedings of MBAO Intl. Conference. 2017; 5: 1-2. San Diego, CA.

[3] Samtani J, Rom C, Friedrich H, Fennimore S, Finn C, Petran A, et al. The status and future of the strawberry industry in the United States HortTechnol. 2019; 29(1):11-24.https://doi.org/10.21273/HORTTECH04135-18

[4] Daugovish O, Knapp S, Gordon T, Fennimore S, Muramoto J, Bolda M. Soil pest management in current California strawberry production: a review. Acta Hortic. 2021; 1309: 701-709.https://doi.org/10.17660/ActaHortic.2021.1309.101

[5] Blok WJ, Lamers JG, Termorshuizen AJ, Bollen GJ. Control of soil-borne plant pathogens by incorporating fresh organic amendments followed by tarping. Phytopathology 2000; 90: 253-259.https://doi.org/10.1094/PHYTO.2000.90.3.253

[6] Shinmura A. Principle and effect of soil sterilization methods by reducing the redox potential of soil. PSJ Soilborne Disease Workshop Report 2004; 22: 2-12 (in Japanese with English Summary).

[7] Fennimore S, Serohijos R, Samtani J, Ajwa H, Subbarao K, Martin F, et al. TIF film, substrates and non-fumigant disinfestation maintain yields. California Agriculture 2013; 67(3): 139-146. https://doi.org/10.3733/ca.v067n03p139

[8] Shennan C, Muramoto J, Koike S, Baird G, Fennimore S, Samtani J, et al. Anaerobic soil disinfestation is a potential alternative to soil fumigation for control of some soil borne pathogens in strawberry production. Plant Pathology 2018; 67(1): 51-66. https://doi.org/10.1111/ppa.12721 
[9] Muramoto J, Shennan C, Mazzola M, Wood T, Miethke E, Resultay E, et al. Use of a summer cover crop as a partial carbon source for anaerobic soil disinfestation in coastal California. Acta Hort. 2020; 1270: 37-44. https://doi.org/10.17660/ActaHortic.2020.1270.4

[10] Muramoto J, Shennan C, Zavatta M, Baird G, Toyama L, Mazola M. Effect of anaerobic soil disinfestation and mustard seed meal for control of charcoal rot in California strawberries. Intl. J. Fruit Sci. 2016; 16: 59-70. https://doi.org/10.1080/15538362.2016.1199993

[11] Daugovish O, Shennan C, Muramoto J, Mazzola M. Carbon source and irrigation affect anaerobic soil disinfestation in strawberry. Proceedings of MBAO Intl. Conference 2015; 12: 1-3. San Diego, CA.

[12] University of California, Davis. 2021. SoilWeb. 14 Apr. 2021; < https://casoilresource.lawr.ucdavis.edu/soilweb-apps/ >.

[13] Butler DM, Kokalis-Burelle N, Muramoto J, Shennan C, McCollum TG, Rosskopf EN. Impact of anaerobic soil disinfestation combined with soil solarization on plant parasitic nematodes and introduced inoculum of soil-borne plant pathogens in raised-bed vegetable production. Crop Protection 2012; 39: 33-40. https://doi.org/10.1016/j.cropro.2012.03.019

[14] Strand L. Integrated pest management for strawberries. University of California Statewide Integrated Pest Management Project. Agriculture and Natural Resource Publication 1994; 3351. 